\title{
VINERS Method for the Multiple Criteria Analysis and Neuromarketing of Best Places to Live
}

\author{
A. Kaklauskas, D. Dzitac, J. Sliogeriene, N. Lepkova, I. Vetloviene
}

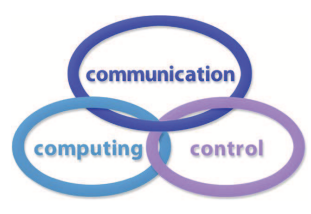

Arturas Kaklauskas*

Vilnius Gediminas Technical University, Vilnius, Lithuania

*Corresponding author: arturas.kaklauskas@vgtu.lt

\section{Domnica Dzitac}

New York University Abu Dhabi, Abu Dhabi, UAE

domnica.dzitac@nyu.edu

Jurate Sliogeriene

Vilnius Gediminas Technical University, Vilnius, Lithuania

jurate.sliogeriene@vgtu.lt

Natalija Lepkova

Vilnius Gediminas Technical University, Vilnius, Lithuania

natalija.lepkova@vgtu.lt

Ingrida Vetloviene

Vilnius Gediminas Technical University, Vilnius, Lithuania

ingrida.vetloviene@vgtu.lt

\begin{abstract}
The best and worst places to live have been analysed in the world for many years and multiple criteria analysis has been used for that purpose. The quality of housing and its environment, pollution, green places, public spaces, physical movement and health, crime rates and individual safety, the wellbeing of youngsters, unemployment, job value, economic scarcity, governance, circadian rhythm, weekly rhythm and other factors are the focus of such analyses that aim to determine levels of positive emotions and happiness in built environment. Questionnaires are the most common tool for such analyses, where inhabitants are asked to rank their happiness experience as a whole in built environment. Many studies demonstrate that happy people are effective in multiple areas of their life including job efficiency, salary, health, human relations, etc. The innovative aspect of this research stems from the fact that biometric technologies (affective attitudes, emotional and physiological states) and the VINERS method developed by the authors are used to determine the best places to live and to serve neuro ads of homes for sale. To do this, rational segments of homebuyers are determined according to their demographic profiles (age, gender, education, marital status, families with children, main source of income), consumer psychographics and behaviour (happy, sad and angry along with valence and heart rate) and then select a rational video ad for such rational segment. The aim of our research is to develop the VINERS Method for the Multiple Criteria Analysis and Neuromarketing of Best Places to Live (VINERS method) by combining the Somatic Marker Hypothesis, biometrics, neuromarketing and COPRAS method. This article presents a case study to demonstrate the VINERS method put to practice.

Keywords: COPRAS and VINERS methods, neuromarketing, multiple criteria analysis, best places to live.
\end{abstract}




\section{Introduction}

Many authors $[5,7,14,15,24,33,34,42,45,49,55]$ have analysed the effect of built environment on the happiness of the people in it. That effect (from the perspective of developing a sustainable community) has also been analysed in the field of sustainability $[7,8,35,39]$.

Common presumption is that happiness is an individual characteristic and each person is the one responsible for his or her own happiness. Happiness is, however, a community characteristic as well, and factors external to the individual can have influence on its levels [8]. Leyden [30] have analysed ten major cities and discovered that self-reported happiness of people is associated with aspects they see as important in their built environments, including issues such as maintenance, convenient public transportation and access to cultural amenities. The empirical data have been collected in the ten cities and they strongly suggest that built environment has an effect on social connections to places that play a vital role in happiness in a city [30]. Florida et al. [16] have determined that the central role in the happiness of cities belongs to human capital, which outperforms income and all other variables. Other researchers $[27,45]$ have also determined that in places where educational attainment is higher people are happier. Does a modern hospital offer true healing? Healing Places analyses different environments and their effect on our physical, spiritual, mental, emotional and social healing. Four dimensions found in healing environments have been identified: built, natural, social and symbolic [18].

People tend to link city centres with feelings of excitement and/or anxiety, and see them as stimulating and lively. In the urban renaissance, an important role is played by evening activities because they keep a town or city alive way beyond normal business hours. A successful urban renaissance requires a more diverse pool of people attracted into city and town centres in the evening and at night [24]. Urry [49] took interest in the ways visitors (and local people too) experience a place. What pleasures the place offers? What are the emotions people feel when they enter a place that is relatively unfamiliar? Urry [49] focuses on popular tourist destinations and shows how specific sites are set up to saturate them with emotions, sometimes frightening and wild, sometimes relaxing and aesthetically pleasing. These emotions then become inseparable from how both tourists and residents imagine and portray those places. Milligan et al. [33] explore positive emotional experiences of older people in the shared community spaces of gardening and social clubs. Milligan et al. [33] demonstrate that the role of social spaces, and shared outdoor gardening activities in particular, can be important and constructive in contributing, in older people's lives, to feelings of self-worth and belonging and emotional expression. Emotions can be joyful, numbing or heartbreaking, but they all have the power to transform our lives, open new horizons or confine us, creating new fixtures or fissures we never expected to find [5].

This paper is structured as follows. This introduction is followed by Section 2 with a demonstration of the VINERS method. Section 3 deliver Case Studies. The paper ends with conclusions and follow-ups on forthcoming research in Section 4.

\section{VINERS method}

The Introduction presents studies showing that a specific demographic segment of buyers should seek housing in the neighborhoods, which they often experience positively. To put it another way, it's best to live feeling as best as possible.

The aim of our research is to develop the VINERS Method for the Multiple Criteria Analysis and Neuromarketing of Best Places to Live (VINERS method) by combining the Somatic Marker Hypothesis (1994), biometrics, neuromarketing and COPRAS methods [52] developed by the applicants. The new VINERS method would make it possible to determine a rational segment of homebuyers by their demographic profiles, consumer psychographics and behaviour and then 


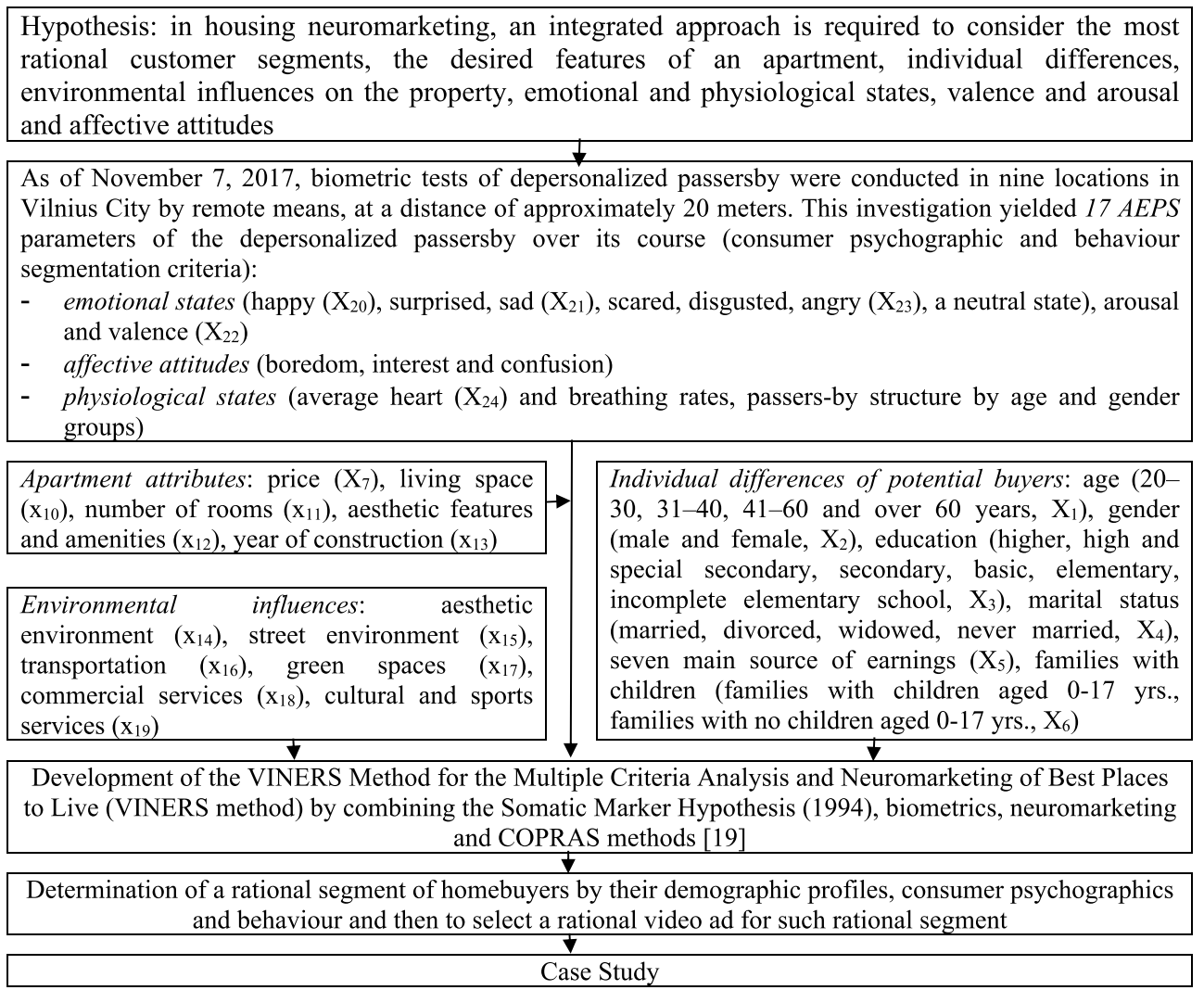

Figure 1: Development of the VINERS Method for the Multiple Criteria Analysis and Neuromarketing of Best Places to Live

to select a rational video ad for such rational segment.

A rational segment of homebuyers by their demographic profiles, consumer psychographics and behaviour can be determined by creating a multiple criteria neuro matrix.

In this research, we hypothesized that in housing neuromarketing an integrated approach is required to consider the most rational customer segments, the desired features of an apartment, individual differences, environmental influences on property, emotional and physiological states, valence and arousal and affective attitudes.

Our research launched on 6 November 2017 is tracking the 17 states of people at nine locations in Vilnius. The goal is to collect data for anonymised affective attitudes, emotional and physiological tests (see Figure 1). The data from our annual tracking activities done in Vilnius with FaceReader 7.1 and the respiration sensor X4M200 were used to establish the AEPS of passers-by taking into account their age and gender.

We have to determine the priority and utility degree of suggested video ads and for that purpose the following system of criteria has been produced to define the specific rational homebuyer segments by their demographic profiles, consumer psychographics and behavior (see Figure 1).

Statistics Lithuania has provided the statistical information about the individual differences of potential buyers $\left(\mathrm{X}_{1}-\mathrm{X}_{6}, \mathrm{X}_{8}, \mathrm{X}_{9}\right)$ under deliberation. The data on apartment attributes $\left(\mathrm{X}_{7}, \mathrm{X}_{10}-\mathrm{X}_{13}\right)$ and environmental influences $\left(\mathrm{X}_{14}-\mathrm{X}_{19}\right)$ came from eight experts on real estate marketing, brokerage and evaluating. Currently over 250 million anonymised affective attitudes, emotional and physiological states (see Figure 1) data entries have been accumulated. It would take a great deal of space to describe all the performed investigations. Therefore, to simplify the write-up of the performed investigation, the use was only of $\mathrm{X}_{20}-\mathrm{X}_{24}$, rather than all the 
available AEPS data (see Table 1).

The research consists of data gathered on these depersonalized bystanders relevant to 17 parameters numbering over 250 million items. It would require considerable room to demonstrate

Table 1: The neuro decision matrix of alternative video ads and the results of its multiple criteria analysis

\begin{tabular}{|c|c|c|c|c|c|c|c|c|c|c|}
\hline \multirow{2}{*}{$\begin{array}{l}\text { Criteria } \\
\text { describing } \\
\text { alternatives }\end{array}$} & \multirow{2}{*}{$\begin{array}{l}\text { Sub-criteria } \\
\text { describing } \\
\text { alternatives }\end{array}$} & \multirow{2}{*}{$\begin{array}{l}\text { Measu- } \\
\text { ring } \\
\text { units }\end{array}$} & \multirow[t]{2}{*}{ Weight } & \multirow[t]{2}{*}{$*$} & \multicolumn{6}{|c|}{$\begin{array}{l}\text { Apartments video alternatives } \\
\text { under comparison }\end{array}$} \\
\hline & & & & & $\mathbf{A}_{1}$ & $\ldots$ & $\ldots$ & $\mathbf{A}_{\mathbf{j}}$ & $\ldots$ & $\overline{A_{n}}$ \\
\hline \multicolumn{11}{|c|}{ Buyer's individual differences (demographic segmentation criteria) } \\
\hline \multirow[t]{4}{*}{ Age $\left(\mathbf{X}_{1}\right)$} & $\mathrm{X}_{11}(20-30$ years $)$ & Points & $\mathrm{q}_{11}$ & + & $\mathrm{x}_{111}$ & $\ldots$ & & $\mathrm{x}_{11 \mathrm{j}}$ & $\ldots$ & $\mathrm{x}_{11 \mathrm{n}}$ \\
\hline & $\mathrm{X}_{12}$ (31-40 years) & Points & $\mathrm{q}_{12}$ & + & $\mathrm{x}_{121}$ & $\ldots$ & $\ldots$ & $\mathrm{x}_{12 \mathrm{j}}$ & $\ldots$ & $\mathrm{x}_{12 \mathrm{n}}$ \\
\hline & $\mathrm{X}_{13}(41-60$ years $)$ & Points & $\mathrm{q}_{13}$ & + & $\mathrm{x}_{131}$ & $\ldots$ & $\ldots$ & $\mathrm{x}_{13 \mathrm{j}}$ & $\ldots$ & $\mathrm{x}_{13 \mathrm{n}}$ \\
\hline & $\mathrm{X}_{14}$ (over 60 years) & Points & $\mathrm{q}_{14}$ & + & $\mathrm{x}_{141}$ & $\ldots$ & $\ldots$ & $\mathrm{x}_{14 \mathrm{j}}$ & $\ldots$ & $\mathrm{x}_{14 \mathrm{n}}$ \\
\hline \multirow[t]{2}{*}{ Gender $\left(\mathrm{X}_{2}\right)$} & $\mathrm{X}_{21}$ (male) & Points & $\mathrm{q}_{21}$ & + & $\mathrm{x}_{211}$ & $\ldots$ & $\ldots$ & $\mathrm{x}_{21 \mathrm{j}}$ & $\ldots$ & $\mathrm{x}_{21 \mathrm{n}}$ \\
\hline & $\mathrm{X}_{22}$ (female) & Points & $\mathrm{q}_{22}$ & + & $\mathrm{x}_{221}$ & $\ldots$ & $\ldots$ & $\mathrm{x}_{22 \mathrm{j}}$ & $\ldots$ & $\mathrm{x}_{22 \mathrm{n}}$ \\
\hline \multirow{6}{*}{$\begin{array}{l}\text { Education } \\
\left(\mathrm{X}_{3}\right)\end{array}$} & $\mathrm{X}_{31}$ (higher) & Points & $\mathrm{q}_{31}$ & + & $\mathrm{x}_{311}$ & $\ldots$ & $\ldots$ & $\mathrm{x}_{31 \mathrm{j}}$ & $\ldots$ & $x_{31 n}$ \\
\hline & $\begin{array}{l}\mathrm{X}_{32} \text { (high/ special } \\
\text { secondary) }\end{array}$ & Points & $\mathrm{q}_{32}$ & + & $\mathrm{x}_{321}$ & $\cdots$ & $\cdots$ & $x_{32 j}$ & $\cdots$ & $\mathrm{x}_{32 \mathrm{n}}$ \\
\hline & $\mathrm{X}_{33}$ (secondary) & Points & $\mathrm{q}_{33}$ & + & $\mathrm{x}_{331}$ & $\ldots$ & $\ldots$ & $\mathrm{x}_{33 \mathrm{j}}$ & $\ldots$ & $\mathrm{x}_{33 \mathrm{n}}$ \\
\hline & $\mathrm{X}_{34}$ (basic) & Points & $\mathrm{q}_{34}$ & + & $\mathrm{x}_{341}$ & $\ldots$ & $\ldots$ & $\mathrm{x}_{34 \mathrm{j}}$ & $\ldots$ & $\mathrm{x}_{34 \mathrm{n}}$ \\
\hline & $\mathrm{X}_{35}$ (elementary) & Points & $\mathrm{q}_{35}$ & + & $\mathrm{x}_{351}$ & 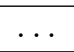 & $\begin{array}{ll}\ldots \\
\ldots\end{array}$ & $\mathrm{x}_{35 \mathrm{j}}$ & $\ldots$ & $\mathrm{x}_{35 \mathrm{n}}$ \\
\hline & $\begin{array}{l}\mathrm{X}_{36} \text { (incomplete } \\
\text { elementary school) }\end{array}$ & Points & $\mathrm{q}_{36}$ & + & $\mathrm{x}_{361}$ & $\cdots$ & $\cdots$ & $\mathrm{x}_{36 \mathrm{j}}$ & $\ldots$ & $x_{36 n}$ \\
\hline \multirow{4}{*}{$\begin{array}{l}\text { Marital } \\
\text { status }\left(\mathrm{X}_{4}\right)\end{array}$} & $\mathrm{X}_{41}$ (married) & Points & $\mathrm{q}_{41}$ & + & $\mathrm{x}_{411}$ & $\ldots$ & $\ldots$ & $\mathrm{x}_{41 \mathrm{j}}$ & $\ldots$ & $\mathrm{x}_{41 \mathrm{n}}$ \\
\hline & $\mathrm{X}_{42}$ (divorced) & Points & $\mathrm{q}_{42}$ & + & $\mathrm{x}_{421}$ & $\ldots$ & $\ldots$ & $\mathrm{x}_{42 \mathrm{j}}$ & $\ldots$ & $\mathrm{x}_{42 \mathrm{n}}$ \\
\hline & $\mathrm{X}_{43}$ (widowed) & Points & $\mathrm{q}_{43}$ & + & $\mathrm{x}_{431}$ & $\ldots$ & $\ldots$ & $\mathrm{x}_{43 \mathrm{j}}$ & $\ldots$ & $\mathrm{x}_{43 \mathrm{n}}$ \\
\hline & $\mathrm{X}_{44}$ (never married) & Points & $\mathrm{q}_{44}$ & + & $\mathrm{x}_{441}$ & $\ldots$ & $\ldots$ & $\mathrm{x}_{44 \mathrm{j}}$ & $\ldots$ & $\mathrm{x}_{44 \mathrm{n}}$ \\
\hline \multirow{7}{*}{$\begin{array}{l}\text { Main source } \\
\text { of earnings } \\
\left(\mathrm{X}_{5}\right)\end{array}$} & $\begin{array}{l}\mathrm{X}_{51} \text { (salary/work } \\
\text { compensation) }\end{array}$ & Points & $\mathrm{q}_{51}$ & + & $\mathrm{x}_{511}$ & $\cdots$ & $\cdots$ & $\mathrm{x}_{51 \mathrm{j}}$ & $\cdots$ & $\mathrm{x}_{51 \mathrm{n}}$ \\
\hline & $\begin{array}{l}\mathrm{X}_{52} \text { (income from } \\
\text { own or family } \\
\text { business) }\end{array}$ & Points & $\mathrm{q}_{52}$ & + & $\mathrm{x}_{521}$ & $\cdots$ & $\cdots$ & $\mathrm{x}_{52 \mathrm{j}}$ & $\cdots$ & $\mathrm{x}_{52 \mathrm{n}}$ \\
\hline & $\begin{array}{l}\mathrm{X}_{53} \text { (income from } \\
\text { agricultural } \\
\text { activities) }\end{array}$ & Points & $\mathrm{q}_{53}$ & + & $\mathrm{x}_{531}$ & $\cdots$ & $\cdots$ & $\mathrm{x}_{53 \mathrm{j}}$ & $\cdots$ & $x_{53 n}$ \\
\hline & $\begin{array}{l}\mathrm{X}_{54} \text { (ownership or } \\
\text { investment income) }\end{array}$ & Points & $\mathrm{q}_{54}$ & + & $\mathrm{x}_{541}$ & $\cdots$ & $\cdots$ & $\mathrm{x}_{54 \mathrm{j}}$ & $\cdots$ & $\mathrm{x}_{54 \mathrm{n}}$ \\
\hline & $\mathrm{X}_{55}($ pension $)$ & Points & $\mathrm{q}_{55}$ & + & $\mathrm{x}_{551}$ & $\ldots$ & $\ldots$ & $x_{55 j}$ & $\ldots$ & $x_{55 n}$ \\
\hline & $\begin{array}{l}\mathrm{X}_{56} \text { (governmental } \\
\text { support) }\end{array}$ & Points & $\mathrm{q}_{56}$ & + & $\mathrm{x}_{561}$ & $\cdots$ & $\ldots$ & $\mathrm{x}_{56 \mathrm{j}}$ & $\cdots$ & $x_{56 n}$ \\
\hline & $\begin{array}{l}\mathrm{X}_{57} \text { (support by } \\
\text { family and/or other } \\
\text { persons) }\end{array}$ & Points & $\mathrm{q}_{57}$ & + & $\mathrm{x}_{571}$ & $\cdots$ & $\cdots$ & $\mathrm{x}_{57 \mathrm{j}}$ & $\cdots$ & $\mathrm{x}_{57 \mathrm{n}}$ \\
\hline \multirow[t]{2}{*}{$\begin{array}{l}\text { Families with } \\
\text { children }\left(\mathrm{X}_{6}\right)\end{array}$} & $\begin{array}{l}\mathrm{X}_{61} \text { (families with } \\
\text { children aged 0-17 } \\
\text { yrs.) }\end{array}$ & Points & $\mathrm{q}_{61}$ & + & $\mathrm{x}_{611}$ & $\cdots$ & $\cdots$ & $\mathrm{x}_{61 \mathrm{j}}$ & $\cdots$ & $\mathrm{x}_{61 \mathrm{n}}$ \\
\hline & $\begin{array}{l}\mathrm{X}_{62} \text { (families with } \\
\text { no children) }\end{array}$ & Points & $\mathrm{q}_{62}$ & + & $\mathrm{x}_{621}$ & $\cdots$ & $\cdots$ & $\mathrm{x}_{62 \mathrm{j}}$ & $\cdots$ & $\mathrm{x}_{62 \mathrm{n}}$ \\
\hline Price $\left(\mathrm{X}_{7}\right)$ & $\mathrm{X}_{71}$ & Points & $\mathrm{q}_{71}$ & - & $\mathrm{x}_{711}$ & $\ldots$ & $\ldots$ & $\mathrm{x}_{71 \mathrm{j}}$ & $\ldots$ & $\mathrm{x}_{71 \mathrm{n}}$ \\
\hline
\end{tabular}


Table 1: (Continued.)

\begin{tabular}{|c|c|c|c|c|c|c|c|c|c|c|}
\hline \multirow{2}{*}{$\begin{array}{l}\text { Criteria } \\
\text { describing } \\
\text { alternatives }\end{array}$} & \multirow{2}{*}{$\begin{array}{l}\text { Sub-criteria } \\
\text { describing } \\
\text { alternatives }\end{array}$} & \multirow{2}{*}{$\begin{array}{l}\text { Measu- } \\
\text { ring } \\
\text { units }\end{array}$} & \multirow[t]{2}{*}{ Weight } & \multirow[t]{2}{*}{$*$} & \multicolumn{6}{|c|}{$\begin{array}{l}\text { Apartments video alternatives } \\
\text { under comparison }\end{array}$} \\
\hline & & & & & $\mathbf{A}_{1}$ & $\ldots$ & $\ldots$ & $\mathbf{A}_{\mathbf{j}}$ & $\ldots$ & $\mathbf{A}_{\mathbf{n}}$ \\
\hline \multirow{3}{*}{$\begin{array}{l}\text { Type of } \\
\text { residential } \\
\text { housing unit } \\
\left(\mathrm{X}_{8}\right)\end{array}$} & $\begin{array}{l}\mathrm{X}_{81} \text { (one unit } \\
\text { house) }\end{array}$ & Points & $\mathrm{q}_{81}$ & + & $\mathrm{x}_{811}$ & .. & $\cdots$ & $\mathrm{x}_{81 \mathrm{j}}$ & $\cdots$ & $\mathrm{x}_{81 \mathrm{n}}$ \\
\hline & $\begin{array}{l}\mathrm{X}_{82}(\text { two-unit } \\
\text { house) }\end{array}$ & Points & $\mathrm{q}_{82}$ & + & $\mathrm{x}_{821}$ & $\cdots$ & $\cdots$ & $\mathrm{x}_{82 \mathrm{j}}$ & $\cdots$ & $\mathrm{x}_{82 \mathrm{n}}$ \\
\hline & $\begin{array}{l}\mathrm{X}_{83} \text { (multi-unit } \\
\text { building dwelling) }\end{array}$ & Points & $\mathrm{q}_{83}$ & + & $\mathrm{x}_{831}$ & $\cdots$ & $\cdots$ & $\mathrm{x}_{83 \mathrm{j}}$ & .. & $\mathrm{x}_{83 \mathrm{n}}$ \\
\hline \multirow{2}{*}{$\begin{array}{l}\text { Ownership } \\
\text { form of } \\
\text { residential } \\
\text { dwelling }\left(\mathrm{X}_{9}\right)\end{array}$} & $\begin{array}{l}\mathrm{X}_{91} \text { (home owner } \\
\text { resident) }\end{array}$ & Points & $\mathrm{q}_{91}$ & + & $\mathrm{x}_{911}$ & $\cdots$ & $\cdots$ & $\mathrm{x}_{91 \mathrm{j}}$ & $\cdots$ & $\mathrm{x}_{91 \mathrm{n}}$ \\
\hline & $\begin{array}{l}\mathrm{X}_{92} \text { (resident in a } \\
\text { rental unit) }\end{array}$ & Points & $\mathrm{q}_{92}$ & + & $\mathrm{x}_{921}$ & 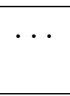 & $\cdots$ & $\mathrm{x}_{92 \mathrm{j}}$ & .. & $\mathrm{x}_{92 \mathrm{n}}$ \\
\hline \multicolumn{11}{|c|}{ Dwelling characteristics } \\
\hline \multicolumn{2}{|c|}{ Residential space $\left(\mathrm{X}_{10}\right)$} & Points & $\mathrm{q}_{100}$ & + & $\mathrm{x}_{1001}$ & ... & $\ldots$ & $\mathrm{x}_{100 \mathrm{j}}$ & $\ldots$ & $\mathrm{x}_{100 \mathrm{n}}$ \\
\hline \multicolumn{2}{|c|}{ Number of rooms $\left(\mathrm{X}_{11}\right)$} & Points & $\mathrm{q}_{110}$ & + & $\mathrm{x}_{1101}$ & .. & $\ldots$ & $\mathrm{x}_{110 \mathrm{j}}$ & $\ldots$ & $\mathrm{x}_{110 \mathrm{n}}$ \\
\hline \multicolumn{2}{|c|}{$\begin{array}{l}\text { Aesthetic and comfort fea- } \\
\text { tures }\left(\mathrm{X}_{12}\right)\end{array}$} & Points & $\mathrm{q}_{120}$ & + & $\mathrm{x}_{1201}$ & $\ldots$ & $\ldots$ & $\mathrm{x}_{120 \mathrm{j}}$ & $\cdots$ & $\mathrm{x}_{120 \mathrm{n}}$ \\
\hline \multicolumn{2}{|c|}{ Construction year $\left(\mathrm{X}_{13}\right)$} & Points & $\mathrm{q}_{130}$ & + & $\mathrm{x}_{1301}$ & $\ldots$ & $\ldots$ & $\mathrm{x}_{130 \mathrm{j}}$ & $\ldots$ & $\mathrm{x}_{130 \mathrm{n}}$ \\
\hline \multicolumn{11}{|c|}{ Environmental influences } \\
\hline \multicolumn{2}{|c|}{ Aplinkos estetika $\left(\mathrm{X}_{14}\right)$} & Points & $\mathrm{q}_{140}$ & + & $\mathrm{x}_{1401}$ & $\ldots$ & $\ldots$ & $\mathrm{x}_{140 \mathrm{j}}$ & $\ldots$ & $\mathrm{x}_{140 \mathrm{n}}$ \\
\hline \multicolumn{2}{|c|}{ Street environment $\left(\mathrm{X}_{15}\right)$} & Points & $\mathrm{q}_{150}$ & + & $\mathrm{x}_{1501}$ & $\ldots$ & $\ldots$ & $\mathrm{x}_{150 \mathrm{j}}$ & $\ldots$ & $\mathrm{x}_{150 \mathrm{n}}$ \\
\hline \multicolumn{2}{|c|}{ Susisiekimas $\left(\mathrm{X}_{16}\right)$} & Points & & + & $\mathrm{x}_{1601}$ & $\ldots$ & $\ldots$ & $\mathrm{x}_{16}$ & $\ldots$ & $\mathrm{x}_{160 \mathrm{n}}$ \\
\hline \multicolumn{2}{|c|}{ Green areas $\left(\mathrm{X}_{17}\right)$} & Points & $\mathrm{q}_{170}$ & + & $\mathrm{x}_{1701}$ & 7 & $\ldots$ & $\mathrm{x}_{170 \mathrm{j}}$ & $\ldots$ & $\mathrm{x}_{170 \mathrm{n}}$ \\
\hline \multicolumn{2}{|c|}{ Commercial services $\left(\mathrm{X}_{18}\right)$} & Points & $\mathrm{q}_{180}$ & + & $\mathrm{x}_{1801}$ & . & $\ldots$ & $\mathrm{x}_{180 \mathrm{j}}$ & $\ldots$ & $\mathrm{x}_{180 \mathrm{n}}$ \\
\hline \multicolumn{2}{|c|}{$\begin{array}{l}\text { Cultural and sporting ser- } \\
\text { vices }\left(\mathrm{X}_{19}\right)\end{array}$} & Points & $\mathrm{q}_{190}$ & + & $\mathrm{x}_{1901}$ & $\ldots$ & $\cdots$ & $\mathrm{x}_{190 \mathrm{j}}$ & ‥ & $\mathrm{x}_{190 \mathrm{n}}$ \\
\hline \multicolumn{11}{|c|}{ Consumer psychographic and behaviour segmentation criteria } \\
\hline \multicolumn{2}{|c|}{ Happiness $\left(\mathrm{X}_{20}\right)$} & Points & $\mathrm{q}_{200}$ & + & $\mathrm{x}_{2001}$ & $\ldots$ & $\ldots$ & $\mathrm{x}_{200 \mathrm{j}}$ & $\ldots$ & $\mathrm{x}_{200 \mathrm{n}}$ \\
\hline \multicolumn{2}{|c|}{ Sadness $\left(\mathrm{X}_{21}\right)$} & Points & $\mathrm{q}_{210}$ & + & $\overline{x_{2101}}$ & $\ldots$ & $\ldots$ & $\mathrm{x}_{210 \mathrm{j}}$ & $\ldots$ & $\mathrm{x}_{210 \mathrm{n}}$ \\
\hline \multicolumn{2}{|c|}{ Valence $\left(\mathrm{X}_{22}\right)$} & Points & $\mathrm{q}_{220}$ & + & $\mathrm{x}_{2201}$ & $\ldots$ & $\ldots$ & $x_{220 j}$ & $\ldots$ & $\mathrm{x}_{220 \mathrm{n}}$ \\
\hline \multicolumn{2}{|c|}{ Angriness $\left(\mathrm{X}_{23}\right)$} & Points & $\mathrm{q}_{230}$ & + & $\mathrm{x}_{2301}$ & & $\ldots$ & $\mathbf{x}_{230 j}$ & ... & $\mathbf{x}_{230 n}$ \\
\hline & & Points & $\mathrm{q}_{240}$ & + & $\mathrm{x}_{2401}$ & $\ldots$ & $\ldots$ & $\mathrm{x}_{240 \mathrm{j}}$ & $\ldots$ & $x_{240 n}$ \\
\hline \multicolumn{5}{|c|}{ Priority of the project alternative } & $\mathbf{P}_{1}$ & & $\ldots$ & $\mathbf{P}_{\mathbf{j}}$ & $\ldots$ & $\mathbf{P}_{\mathbf{n}}$ \\
\hline \multicolumn{5}{|c|}{ Degree of utility of the project } & $\mathbf{N}_{1}$ & & $\ldots$ & $\mathbf{N}_{\mathrm{j}}$ & $\ldots$ & $\mathbf{N}_{\mathrm{n}}$ \\
\hline
\end{tabular}

Tables 1-3 containing the data on these 17 parameters of depersonalized bystanders. Therefore fragments of variables relevant to the theoretical study on these data appear in Table 1 . Tables 2 and 3 illustrate fragments calculated practically.

The system of criteria is then used as the basis for a multiple criteria neuro decision matrix where its columns represent $n$ alternative video ads and its rows are filled with detailed quantitative information of each alternative. Our quantitative information includes the systems of criteria, measuring units, values and weights, and the minimising or maximising criterion.

In marketing segmentation, we take a large cohort of current and potential customers, and, based on the above features, divide it into customer sub-groups (segments). In general, the goal of segmentation is to identify the sub-groups of customers that are most likely to buy a dwelling or bring the best profit, and as a result these potential consumers can become target demographic, behavioral or other significant segments. In marketing segmentation, it is accepted 
that different marketing segments need different advertising approaches with different green housing options (based on characteristics, prices, environmental influences, etc.). By applying marketing segmentation, we seek to create profiles of the main potential home buyers.

The authors analysed scientific articles and statistical data and their analysis shows that dwelling buyer needs and buying habits depend on age (X1), gender (X2), education (X3), marital status (X4) and other factors. Buyers in the age group between 18 and 34, for instance, are usually looking for cheaper properties and tend to commit smaller sums for home buying than older buyers; smaller incomes is a factor. Gender differences in the choice of home show that women are more interested in the size of the kitchen, bathroom and wardrobes. Men, on the other hand, tend to focus on recreational spaces, pools and tubs. The size of and requirements for real estate investments can be also inferred from marital status. [11] compared married and single buyers and determine that those that are married have larger incomes and, naturally, can afford better apartment. The affordability of apartment and the environment in which their children will grow are the two main points stressed by these buyers. Single buyers are quite different and their gender also plays a role: single men choose properties closer to entertainment, recreation and sports centres, whereas single women prefer properties closer to their friends or family. To do a good job, real estate brokers need to understand how buyers react to marketing stimuli such as needs, personality, motives, expectations and experiences. Exposed to the same kinds of stimuli individuals often identify them in different ways, often focusing on elements they find important [2]. Expectations among female participants are generally higher than among men, and also higher among younger participants than among older. The least-educated participants have the highest expectations regarding the time when they will buy their own property and with every step up the education ladder expectations fall lower. Students had the highest expectations related to transport links, proximity to shops, schools and kindergartens, socio-economic and financial factors, greater autonomy, and a sense of peace [21].

Eight experts of property marketing, brokers and valuators applied expert methods to determine criteria values and weights (see Tables 2 and 3). The eight real estate experts evaluated how specific characteristics of housing units correspond with the needs of specific buyers based on a 10 -point scale (where 1 is not very important, and 10 is very important). Their basis for the evaluation included the aforementioned and worldwide practices as well as their long-time. A method of complex determination of the weights of the criteria taking into account their quantitative and qualitative characteristics [26] was applied for criteria weights calculations.

The COPRAS method [52] is applied to determine the priority and utility degree of a video ad. The utility degree $\left(N_{j}\right)$ can be between $0 \%$ and $100 \%$ and it depends, directly and proportionally, on the relative impact the criterial values $x_{i j}$ and weights $q_{i}$ make on the end result. The COPRAS Method [52] ensures that an adequate system of criteria defines any analyzed alternatives. Additionally, the weights and degrees of utility of these alternatives are presumed to link, both by direct and proportional dependence, to the values and weights of those criteria.

\section{Case study}

As of November 7, 2017, biometric tests of depersonalized passersby were conducted in nine locations in Vilnius City by remote means, at a distance of approximately 20 meters. This investigation yielded 17 affective attitudes, physiological and emotional states parameters (see Figure 1) of the depersonalized passersby over its course. Over 250 million items of data were gathered on these 17 parameters of depersonalized passersby during the course of this investigation. Since these 17 parameters of depersonalized passersby would take a tremendous amount of space to demonstrate in Tables 1,2 and 3 that are under deliberation, fragments of these data for a theoretical analysis are illustrated as variables in Table 1. Meanwhile fragments of practical 
calculations appear as numbers in Tables 2 and 3.

\subsection{Detailed system of criteria defining the alternative video ads}

This study has looked at the following groups of criteria: individual differences of potential buyers, apartment attributes, environmental influences, and consumer psychographic and behaviour segmentation criteria.

\section{Buyer's individual differences (demographic segmentation criteria)}

When users are looking for suitable options of apartment, the process can be lengthy and complicated because they may have many factors to consider. They need to take into account their budget and what facilities they need such as supermarkets, public transport or public schools available for their children. Most home buyers also find it important to look for a property that will grow in value over time so that in a few years they can sell it and move up the property ladder easier [28].

Socioeconomic and demographic characteristics may influence how a resident evaluates the neighbourhood, as may a normative element of the apartment environment preferred based on the person's lifestyle, experience, and inclinations. The objective characteristics evaluated by the resident in residential environment are the attributes of a specific house and neighbourhood. When the subjective individual perception of the residential environment, including the quality of the neighbourhood, matches the person's needs and expectations, it results in residential satisfaction [43]. When a person is satisfied with his or her residential environment, it means the perceived situation and the desired situation are a close match; deviation from preferred conditions, on the other hand, leads to dissatisfaction [19].

A range of studies spanning several decades show that neighbourhood satisfaction depends on age, sex, marital status, income, education, and race $[6,25,40,41,48]$ focused on older residents in Spain and found higher satisfaction among Madrid residents living alone or only with a spouse. The satisfaction was also higher among women [19].

Marriage, change in jobs, fertility, educational issues or living with old parents may make public rental apartment tenants reconsider the objective public rental apartment factors in light of changing personal requirements.

Looking at group and personal influences would mean focusing on mutual relationships between potential home buyers and their co-workers, family members, friends and other individuals. To limit the scope of this research, these factors were, therefore, excluded from the development of VINERS method, even though ethnicity, culture, group and personal influences affect the needs and behaviour of potential home buyers, as has been shown. These factors will be incorporated into the VINERS method at later stages of the research.

\section{Dwelling characteristics and environmental influences}

Intrinsic and extrinsic characteristics influence the choice of a home. Intrinsic are the factors that define the apartment unit itself (flat, house or building), i.e. the number of rooms, balconies, windows, the floor, aesthetic properties, decor, features and amenities, etc. Extrinsic are the features of the location, such as green spaces (public parks and gardens), urban quality (roads, buildings, squares), public transport, social context, proximity to commercial areas or other centralities, picturesque views, historical significance of the area, pollution (acoustic, atmospheric), and so on [10].

A rapid increase of railway lines, both operational and under construction, leads to an increase in the number of buildings that suffer adverse effects of ground-borne vibration (e.g. 
indoor noise and shaking) [17].

Ventilation regulates indoor air parameters, such as air temperature, air speed, relative humidity and concentrations of chemical substances in the air, and this way creates thermally comfortable environments with acceptable indoor air quality [44].

Building height determines various parameters. Negative correlation, for instance, links air temperature, humidity, $\mathrm{PM}_{2.5}, \mathrm{PM}_{10}$, and $\mathrm{C}_{\mathrm{O} 2}$ to building height - the higher the building, the lower the values. In contrast, ozone generally increased with building height, and the values of $\mathrm{NO} 2$ were less consistent. The correlation between $\mathrm{PM}, \mathrm{CO}_{2}$, and $\mathrm{O}_{3}$ concentrations and floor height was stronger than between local wind speed and direction and floor height [1].

Indoor temperature and humidity fluctuations can be moderated by means of building materials. Phase change materials can be used to moderate the indoor temperature variations and reduce the energy consumption of HVAC systems; they absorb or release large amount of thermal heat at a constant temperature in phase change process. Well known is also the fact that indoor air humidity may have a significant influence on the living environment and, thus, on the comfort and health of its occupants. Humidity is an important factor. It influences both indoor air quality and thermal comfort [50].

When households make the decision which home to buy, they consider such important factors as the costs of apartment, time and transport, and the benefits that the site offers [10]. Available amenities and local incomes are usually the key factors in choosing a location. Incomes, in part, depend on the interaction between the demand and supply of labour. In terms of the choice of a city, residents, workers and businesses also consider the overall quality of life offered by the city [10].

Papamanolis [37] believes that environmental factors constantly change. Those that affect buildings are all variable [38]; among them are air temperature, moisture, solar radiation, precipitation, wind, noise and air pollution. All of them display fluctuations in many aspects. The fluctuations in some cases span a wide range of values (e.g. in case of air temperature, solar radiation, humidity and wind speed), occasionally varying between negative and positive effects. Other factors, such as pollution and ambient noise, have fluctuations ranging from negligible to (usually) negative. Beyond the intensity, important is also the frequency with which environmental factors affecting buildings vary. The same can be said about air pollution, especially in urban areas. A storm or a pollution event is a good example. At the building shell surface, the wind can serve as a medium for ventilation, pollution dispersion, natural cooling or thermal exchange. It can also act as a factor involved in structural integrity. Fluctuating values of environmental factors directly affect functioning of the systems installed in buildings in order to control the impact. The response of systems to variable conditions is a critical factor in their efficiency. Only when they are adapted to address the effects of any prevailing factors, passive systems can be efficient. Active systems are different. They show more flexibility when they respond to the fluidity of the environmental impact. A good example of a system that "behaves" according to the prevailing conditions are dynamic louvers - they react to the actual conditions to make sure the control of daylight and solar heat gains is optimal. Every step towards higher levels of adaptability to a variety of conditions makes these systems more effective [37]. Inclusion of the environmental factors mentioned above in the neuro decision matrix would involve a wide scope of research.

Potential home buyers make decisions slowly due to the complexities of decision making, often associated with a need for a large amount of funds and acceptance of long term obligations. They analyze various alternatives and circumstances as well as compare and consider different offers. Researchers $[13,46,47,51]$ noticed the huge influence emotions play on decision making.

Exceptional as well as digital marketing means must be employed to interest buyers in proposed apartment units. These promise buyers more possibilities for choosing a desired dwelling. 
Applications of integrated neuro-marketing means make it possible to evaluate the needs of potential real estate buyers relevant to their emotions, present the most suitable offers and encourage decision making.

Traditional marketing means are insufficient when wanting to interest buyers in new, innovative products and to orient them towards firm and perspective albeit untraditional decision making. Thus this study undertook an analysis of the video neuro-advertising used in the real estate market of Vilnius City. This video neuro-advertising was submitted to the inhabitants of four eldership districts of Vilnius (specifically to Naujamiestis, Verkiai, Old Town and Žirmūnai). The selection of these specific districts were due to their reflecting a social distribution that makes it possible to forecast the desired level of apartment for acquisition, specific needs for such and the abilities to accept adequate obligations. For example, homeowners in the Old Town manage the most expensive apartment in Vilnius (where the price per one square meter is, on average, 2900 Euros). These buyers are able to consider the highest-class projects being offered when their family structures and needs change. Conversely, in the Žirmūnai district, residential apartment constructed long ago dominate; these units are notable for their lesser liquidity and significantly lower prices (where the price per one square meter is, on average, around 1300 Euros). Real estate companies and brokers notice that residents change their apartment units 3-4 times on average during their entire lives. Therefore the interest in real estate offerings is always relevant to various groups of residents during different stages of their lives. That is the reason different residents of these Vilnius districts, representing various social groups, were selected for this study. Data on the selected district residents came for the Lithuanian Department of Statistics in 2018 [29] following the submission of a targeted query. The data received permitted dividing the residents by age, gender, education, marital status and family composition, main sources for earnings and the type of apartment in which the persons resided and the form of its ownership. Conducted interviews established their needs to acquire or change their apartment units.

\section{Consumer psychographic and behavioral segmentation}

A number of investigations in the area of consumer psychographic and behavioral segmentation have been performed $[4,12,23]$. For example, the research performed by [12] investigated emotions to determine if they can be considered as a suitable variable for segmenting museum visitors. The reports from the segment with more positive emotions indicated perceptions of the museum as being more attractive and unique at the museum, than the other segment did, along with a higher level of satisfaction [12].

\subsection{First-step segmentation}

In marketing segmentation, we take a large cohort of current and potential customers, and, based on the above features, divide it into customer sub-groups (segments). In general, the goal of segmentation is to identify the sub-groups of customers that are most likely to buy a dwelling or bring the best profit and as a result these potential consumers can become target demographics, behavioural or other significant segments. In marketing segmentation, it is accepted that different marketing segments need different advertising alternatives with different housing options (based on characteristics, prices, environmental influences, etc.). By applying marketing segmentation we seek to create profiles of the main potential home buyers.

Our research uses the two-step segmentation technique of potential home buyers. In geographic segmentation, the properties in question were grouped taking into account the urban districts (neighbourhoods). In the second stage dedicated to demographic, psychographic and behavioural segmentation, the aggregate neuro decision matrices created for each neighbourhood 
in question were narrowed down to cover more specific buyer segments. By using the two segmentation stages real estate brokers can optimise their marketing resources and reach the most rational potential clients.

A team of eight property experts from Vilnius evaluated ads and matched them with a certain group of residents following the definition provided by Statistics Lithuania. Four relative age groups were established: Group I with people aged 20 to 30, Group II with people aged 31 to 40, Group III with people aged 41 to 60 and Group IV with people aged over 60.

Our approach includes the first step segmentation for which the object of our analysis, i.e. the urban district, was divided into four neighbourhoods (Naujamiestis, Verkiai, Old Town, Žirmūnai). Then, in the second stage, we reclassify the sub-segments established in the first stage and determine a rational number of segments (see Table 2).

Table 2: The fragment of aggregate general neuro decision-making matrix during the time of first-step segmentation in the Old Town District

\begin{tabular}{|c|c|c|c|c|c|c|c|c|c|c|c|c|c|c|}
\hline \multirow{2}{*}{$\begin{array}{l}\text { Criteria } \\
\text { describing } \\
\text { alternatives }\end{array}$} & \multirow{2}{*}{$\begin{array}{l}\text { Cri- } \\
\text { teria } \\
\text { No } \\
\end{array}$} & \multirow{2}{*}{$\begin{array}{l}\text { Sub-criteria } \\
\text { describing } \\
\text { alternatives }\end{array}$} & \multirow[t]{2}{*}{$*$} & \multirow[t]{2}{*}{ Weight } & \multirow{2}{*}{$\begin{array}{l}\text { Number } \\
\text { of inhabi- } \\
\text { tants }\end{array}$} & \multicolumn{9}{|c|}{$\begin{array}{l}\text { Housing unit video ad } \\
\text { alternatives under comparison }\end{array}$} \\
\hline & & & & & & 1 & 2 & & 15 & 16 & 17 & 18 & 19 & 20 \\
\hline \multicolumn{15}{|c|}{ Buyer's individual differences (demographic segmentation criteria) } \\
\hline \multirow[t]{4}{*}{ Age $\left(\mathrm{X}_{1}\right)$} & 1 & $20-30$ years & + & 0.0079 & 4635 & 3 & 6 & $\ldots$ & 3 & 5 & 1 & 6 & 1 & 8 \\
\hline & 2 & $31-40$ years & + & 0.0047 & 2895 & 6 & 6 & $\ldots$ & 6 & 8 & 2 & 8 & 3 & 9 \\
\hline & 3 & $41-60$ years & + & 0.0381 & 4981 & 4 & 5 & $\ldots$ & 8 & 9 & 7 & 6 & 8 & 4 \\
\hline & 4 & Over 60 years & + & 0.027 & 3286 & 7 & 7 & $\ldots$ & 3 & 3 & 2 & 3 & 2 & 4 \\
\hline \multirow{2}{*}{ Gender $\left(\mathrm{X}_{2}\right)$} & 5 & Male & + & 0.0097 & 7060 & 7 & 9 & $\ldots$ & 8 & 8 & 6 & 8 & 6 & 9 \\
\hline & 6 & Female & + & 0.0128 & 8737 & 8 & 10 & $\ldots$ & 9 & 8 & 5 & 7 & 8 & 8 \\
\hline \multirow{6}{*}{$\begin{array}{l}\text { Education } \\
\left(\mathrm{X}_{3}\right)\end{array}$} & 7 & higher & + & 0.060 & 7400 & 7 & 6 & $\ldots$ & 9 & 7 & 9 & 7 & 9 & 6 \\
\hline & 8 & $\begin{array}{l}\text { high and special } \\
\text { secondary }\end{array}$ & + & 0.016 & 1938 & 7 & 8 & $\ldots$ & 5 & 7 & 4 & 7 & 4 & 8 \\
\hline & 9 & secondary & + & 0.042 & 5227 & 6 & 7 & $\ldots$ & 2 & 7 & 1 & 7 & 2 & 8 \\
\hline & 10 & basic & + & 0.012 & 1442 & 5 & 6 & $\ldots$ & 4 & 4 & 1 & 4 & 1 & 4 \\
\hline & 11 & elementary & + & 0.012 & 1521 & 4 & 5 & $\ldots$ & 1 & 2 & 1 & 2 & 1 & 3 \\
\hline & 12 & $\begin{array}{l}\text { incomplete elementary } \\
\text { school }\end{array}$ & + & 0.001 & 140 & 3 & 4 & 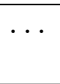 & 1 & 2 & 1 & 2 & 1 & 4 \\
\hline \multirow{4}{*}{$\begin{array}{l}\text { Marital status } \\
\left(\mathrm{X}_{4}\right)\end{array}$} & 13 & married & + & 0.057 & 6995 & 7 & 6 & $\ldots$ & 7 & 9 & 8 & 9 & 8 & 9 \\
\hline & 14 & divorced & + & 0.016 & 1988 & 9 & 9 & $\ldots$ & 4 & 6 & 7 & 6 & 7 & 6 \\
\hline & 15 & widowed & + & 0.011 & 1352 & 7 & 8 & $\ldots$ & 5 & 7 & 5 & 8 & 4 & 8 \\
\hline & 16 & never married & + & 0.053 & 6556 & 9 & 8 & $\ldots$ & 4 & 6 & 7 & 6 & 7 & 8 \\
\hline \multirow{7}{*}{$\begin{array}{l}\text { Main source } \\
\text { of earnings } \\
\left(\mathrm{X}_{5}\right)\end{array}$} & 17 & $\begin{array}{l}\text { salary/work } \\
\text { compensation }\end{array}$ & + & 0.069 & 8445 & 7 & 8 & $\ldots$ & 5 & 7 & 4 & 7 & 5 & 7 \\
\hline & 18 & $\begin{array}{l}\text { (income from own or } \\
\text { family business }\end{array}$ & + & 0.004 & 534 & 8 & 8 & $\ldots$ & 9 & 8 & 9 & 7 & 9 & 7 \\
\hline & 19 & $\begin{array}{l}\text { income from } \\
\text { agricultural activities }\end{array}$ & + & 0.0001 & 18 & 8 & 8 & $\cdots$ & 9 & 8 & 6 & 7 & 6 & 7 \\
\hline & 20 & $\begin{array}{l}\text { ownership or } \\
\text { investment income }\end{array}$ & + & 0.0006 & 74 & 7 & 7 & $\ldots$ & 9 & 6 & 9 & 6 & 9 & 6 \\
\hline & 21 & pension & + & 0.024 & 3021 & 4 & 5 & $\ldots$ & 2 & 2 & 1 & 3 & 1 & 4 \\
\hline & 22 & governmental support & + & 0.004 & 551 & 1 & 5 & $\ldots$ & 1 & 1 & 1 & 1 & 1 & 1 \\
\hline & 23 & $\begin{array}{l}\text { support by family } \\
\text { and/or other persons }\end{array}$ & + & 0.045 & 5493 & 1 & 4 & $\ldots$ & 1 & 1 & 1 & 1 & 1 & 1 \\
\hline \multirow{2}{*}{$\begin{array}{l}\text { Families with } \\
\text { children (total } \\
\text { 4152) }\left(\mathrm{X}_{6}\right)\end{array}$} & 24 & $\begin{array}{l}\text { families with children } \\
\text { aged } 0-17 \text { yrs. }\end{array}$ & + & 0.016 & 2023 & 6 & 6 & $\cdots$ & 7 & 9 & 7 & 9 & 7 & 8 \\
\hline & 25 & $\begin{array}{l}\text { families with no } \\
\text { children aged 0-17 yrs. }\end{array}$ & + & 0.017 & 2129 & 8 & 8 & $\ldots$ & 6 & 7 & 8 & 7 & 8 & 7 \\
\hline
\end{tabular}


Table 2: (Continued.)

\begin{tabular}{|c|c|c|c|c|c|c|c|c|c|c|c|c|c|c|}
\hline \multirow{2}{*}{$\begin{array}{l}\text { Criteria } \\
\text { describing } \\
\text { alternatives }\end{array}$} & \multirow{2}{*}{$\begin{array}{l}\text { Cri- } \\
\text { teria } \\
\text { No }\end{array}$} & \multirow{2}{*}{$\begin{array}{l}\text { Sub-criteria } \\
\text { describing } \\
\text { alternatives }\end{array}$} & \multirow[t]{2}{*}{$*$} & \multirow[t]{2}{*}{ Weight } & \multirow{2}{*}{$\begin{array}{l}\text { Nnumber } \\
\text { of } \\
\text { inhabitants }\end{array}$} & \multicolumn{9}{|c|}{$\begin{array}{l}\text { Housing unit video ad alternatives } \\
\text { under comparison }\end{array}$} \\
\hline & & & & & & 1 & 2 & $\ldots$ & 15 & 16 & 17 & 18 & 19 & 20 \\
\hline \multicolumn{15}{|c|}{ Dwelling characteristics } \\
\hline Price $\left(X_{7}\right)$ & 26 & $\begin{array}{l}\text { Average price } \\
\text { (euro/sq. m.) }\end{array}$ & - & 1 & & 1830 & 1450 & $\cdots$ & 1770 & 1280 & 4050 & 1290 & 3710 & 1320 \\
\hline \multirow{3}{*}{$\begin{array}{l}\text { Type of } \\
\text { residential } \\
\text { housing unit } \\
\left(\mathrm{X}_{8}\right)\end{array}$} & 27 & one unit house & + & 0.002 & 285 & 5 & 4 & $\ldots$ & 9 & 7 & 9 & 7 & 9 & 7 \\
\hline & 28 & \begin{tabular}{l|l|} 
two-unit \\
house
\end{tabular} & + & 0.003 & 335 & 6 & 4 & $\ldots$ & 9 & 7 & 9 & 7 & 9 & 7 \\
\hline & 29 & $\begin{array}{l}\text { multi-unit } \\
\text { building } \\
\text { dwelling }\end{array}$ & + & 0.138 & 16969 & 8 & 9 & $\cdots$ & 7 & 9 & 7 & 9 & 7 & 9 \\
\hline \multirow{2}{*}{$\begin{array}{l}\text { Ownership form } \\
\text { of residential } \\
\text { dwelling (18917) } \\
\left(\mathrm{X}_{9}\right)\end{array}$} & 30 & $\begin{array}{l}\text { home owner } \\
\text { resident }\end{array}$ & + & 0.111 & 13681 & 8 & 7 & $\cdots$ & 7 & 9 & 6 & 9 & 6 & 8 \\
\hline & 31 & $\begin{array}{l}\text { resident in a } \\
\text { rental unit }\end{array}$ & + & 0.027 & 3328 & 7 & 8 & $\cdots$ & 5 & 8 & 5 & 8 & 5 & 7 \\
\hline $\begin{array}{l}\text { Building } \\
\text { materials }\left(X_{10}\right)\end{array}$ & 32 & & + & 0.18 & Points & 7 & 5 & $\cdots$ & 8 & 6 & 9 & 6 & 9 & 7 \\
\hline $\begin{array}{l}\text { Noise and air } \\
\text { pollution }\left(X_{11}\right)\end{array}$ & 33 & & + & 0.10 & Points & 8 & 8 & $\ldots$ & 9 & 9 & 8 & 8 & 8 & 7 \\
\hline $\begin{array}{l}\text { Energy } \\
\text { consumption } \\
\text { (floor heating, } \\
\text { renewable } \\
\text { energy sources } \\
\text { and etc.) }\left(\mathrm{X}_{12}\right) \\
\end{array}$ & 34 & & + & 0.27 & Points & 6 & 7 & $\ldots$ & 8 & 7 & 8 & 9 & 9 & 7 \\
\hline $\begin{array}{l}\text { Aesthetic } \\
\text { properties }\left(\mathrm{X}_{13}\right)\end{array}$ & 35 & & + & 0.05 & Points & 7 & 7 & $\cdots$ & 9 & 7 & 9 & 8 & 9 & 7 \\
\hline \multicolumn{15}{|c|}{ Environmental influences } \\
\hline $\begin{array}{l}\text { Urban quality } \\
\text { (infrastructure) } \\
\left(\mathrm{X}_{14}\right)\end{array}$ & 36 & & + & 0.22 & Points & 7 & 7 & $\cdots$ & 8 & 6 & 9 & 6 & 9 & 7 \\
\hline $\begin{array}{l}\text { Green spaces } \\
\left(\mathrm{X}_{15}\right)\end{array}$ & 37 & & + & 0.18 & Points & 7 & 7 & $\cdots$ & 9 & 7 & 6 & 7 & 7 & 6 \\
\hline \multicolumn{15}{|c|}{ Consumer psychographic and behaviour segmentation } \\
\hline Happiness & 38 & & + & 0.1 & Points & 0.14 & 0.14 & $\ldots$ & 0.14 & 0.14 & 0.14 & 0.14 & 0.14 & 0.14 \\
\hline Arousal & 39 & & + & 0.1 & Points & 0.33 & 0.33 & $\ldots$ & 0.33 & 0.33 & 0.33 & 0.33 & 0.33 & 0.33 \\
\hline Boredom & 40 & & - & 0.1 & Points & 0.06 & 0.06 & $\ldots$ & 0.06 & 0.06 & 0.06 & 0.06 & 0.06 & 0.06 \\
\hline Interest & 41 & & + & 0.1 & Points & 0.01 & 0.01 & $\ldots$ & 0.01 & 0.01 & 0.01 & 0.01 & 0.01 & 0.01 \\
\hline Heart rate & 42 & & + & 0.1 & Points & 66 & 66 & $\ldots$ & 66 & 66 & 66 & 66 & 66 & 66 \\
\hline Breathing rate & 43 & & + & 0.1 & Points & 16.7 & 16.7 & $\ldots$ & 16.7 & 16.7 & 16.7 & 16.7 & 16.7 & 16.7 \\
\hline \multicolumn{6}{|c|}{ Priority of housing unit video alternatives under comparison } & 18 & 12 & $\ldots$ & 20 & 6 & 1 & 7 & 2 & 9 \\
\hline \multicolumn{6}{|c|}{$\begin{array}{l}\text { Utility degree of housing unit video alternatives under } \\
\text { comparison }(\%)\end{array}$} & 74,17 & 75,88 & $\ldots$ & 74,17 & 78,48 & 100 & 78,28 & 94,49 & 77,7256 \\
\hline
\end{tabular}

A method of complex determination of the weights of the criteria taking into account their quantitative and qualitative characteristics [26] was applied for criteria weights calculations.

The group of experts were shown 20 video ads taken from property offerings assigned to the relevant group of potential homebuyers. A sum segmentation neuro decision matrix for the Old Town was compiled based on this data (see Table 2). On a 10-point scale, each expert assigned a certain number of points to each apartment in the matrix based on its acquisition/interest potential and taking into account the needs, financial capacity and family composition of typical social groups, as well as market trends, acquisitions and stereotypes. Similar sum segmentation neuro 
decision matrixes were compiled for the other three districts of Vilnius (Verkiai, Naujamiestis and Žirmūnai). Table 3 has been analogically filled out.

The COPRAS technique [52] and the data from Table 2 has been used to determine the potential effect of the video ads being analyzed on passers-by. The seventeenth video ad $\left(\mathrm{N}_{17}\right.$ $=100 \%)$ made the biggest potential impact on passers-by. The lowest potential impact on passers-by impressions and feelings was made by the fifteenth ad $\left(\mathrm{N}_{15}=74,17 \%\right)$.

With the buyer segments in the Old Town determined (see Table 2), more rational marketing is then possible for the highest success. The individual buyer differences, environmental influences and apartment attributes related to each segment of buyers assists with more effective ad targeting.

To determine the buyer segments in the Old Town, we start with the broadest possible sample (see Table 2) and then narrow it down to establish more specific groups (see Table 3) because the majority of property agents have multiple buyer personas.

\subsection{Second-step segmentation}

The Old Town's sum neuro decision matrix created as part of the first-step segmentation (see Table 2) has been used as the basis for a more specific neuro decision matrix in the second stage. Table 3 shows one of the matrixes created in the second stage.

Fragments of available 250 millions AEPS data (see Figure 1) are displayed as variables in Tables 1-3, because displaying the 17 parameters of these depersonalized passersby data in Tables 1-3 which are under deliberation would take up a great deal of space. Meanwhile fragments of the practical calculations appear as numbers in Tables 2 and 3.

An analysis of male and female respondents of various ages was for establishing an integrated, rational segment of potential buyers and an effective advertisement for housing in the Old Town of Vilnius. The purpose of this analysis was to establish the project that would be most rational for advertising at this time to the group of a specific age. Three video alternatives were shown to the eight aforementioned experts.

The first alternative was Video 1 on the Live Square project (https://livesquare.1t/en/). Live Square apartments are modern and high-quality home spaces. Apartments with balconies and terraces are designed for three LIVE SQUARE residential buildings.

The second alternative was Video 2 on Magnus Rezidencija [Magnus Residence] (http: //gedimino47.1t/). Magnus Rezidencija is an exceptional oasis of residential housing and commercial facilities on Gedimino Prospect, a central street of Vilnius City. Cozy terraces, high windows, bright staircases and a separate playground for children in a private yard have been equipped for this project. A safe neighborhood, privacy and convenience distinguish this project.

The third alternative is Centro Rezidencija [Central Residence] (https://centrorezidencija . lt/galerija/). This project consists of eight residential buildings consisting of 4 to 9 stories. Stage I of this project has concluded building 4-5 and 7-storey buildings that contain 115 housing units measuring from 35 to 68 square meters. The construction for Stage II of this project consists of three residential buildings: two have 7 storeys and one has 6 storeys. During this stage, the offer is for 133 housing units measuring from 29 to 85 square meters. Stage III of this project consists of three residential buildings, one is 8-stories and two are 9-stories high. The units offered for sale measure from 25 to 98 square meters. Central to every stage of Centro Rezidencija will be the formation of a closed, internal yard complete with safe playgrounds for children, rest zones and an environment arranged by landscaping specialists. There is an underground parking lot for automobiles beneath the buildings. It is easily accessible by elevator operating directly from the staircases. 
Table 3: Neuro decision matrix created as part of second-step segmentation in the Old Town

\begin{tabular}{|c|c|c|c|c|c|c|c|c|c|c|c|c|c|c|c|}
\hline \multirow{4}{*}{$\begin{array}{l}\text { Criteria } \\
\text { describing } \\
\text { alternatives }\end{array}$} & \multirow{4}{*}{$\begin{array}{l}\text { Measu- } \\
\text { ring } \\
\text { units }\end{array}$} & \multirow{4}{*}{ Weight } & \multirow[t]{4}{*}{$*$} & \multicolumn{12}{|c|}{ Video alternatives for the age groups } \\
\hline & & & & \multirow{2}{*}{\multicolumn{4}{|c|}{\begin{tabular}{|l|} 
Video 1 \\
Age demographics for \\
advertising (years, male \\
\& female) \\
\end{tabular}}} & \multirow{2}{*}{\multicolumn{4}{|c|}{\begin{tabular}{|l|} 
Video 2 \\
Age demographics for \\
advertising (years, male \\
\& female)
\end{tabular}}} & \multirow{2}{*}{\multicolumn{4}{|c|}{\begin{tabular}{|l|} 
Video 3 \\
Age demographics for \\
advertising (years, male \\
\& female)
\end{tabular}}} \\
\hline & & & & & & & & & & & & & & & \\
\hline & & & & \begin{tabular}{|l|}
$\mathrm{x}_{11}$ \\
$(20-30)$ \\
\end{tabular} & \begin{tabular}{|l|}
$\mathrm{x}_{12}$ \\
$(31-40)$ \\
\end{tabular} & \begin{tabular}{|l|}
$\mathrm{x}_{13}$ \\
$(41-50)$
\end{tabular} & \begin{tabular}{|l|}
$\mathrm{x}_{14}$ \\
$(51-60)$
\end{tabular} & $\begin{array}{l}\mathrm{x}_{11} \\
(20-30)\end{array}$ & \begin{tabular}{|l|}
$\mathrm{x}_{12}$ \\
$(31-40)$
\end{tabular} & \begin{tabular}{|l|}
$\mathrm{x}_{13}$ \\
$(41-50)$
\end{tabular} & \begin{tabular}{|l|}
$\mathrm{x}_{14}$ \\
$(51-60)$
\end{tabular} & $\begin{array}{l}\mathrm{x}_{11} \\
(20-30)\end{array}$ & $\begin{array}{l}\mathrm{x}_{12} \\
(31-40)\end{array}$ & \begin{tabular}{|l|}
$\mathrm{x}_{13}$ \\
$(41-50)$
\end{tabular} & $\begin{array}{l}\mathrm{x}_{14} \\
(51-60)\end{array}$ \\
\hline $\begin{array}{l}\text { Residential } \\
\text { space }\end{array}$ & Points & 0,1 & + & \begin{tabular}{|l|l}
7 & \\
\end{tabular} & 8 & \begin{tabular}{|l|l}
8 & \\
\end{tabular} & 6 & 7 & 8 & 9 & 6 & 8 & 9 & 9 & 7 \\
\hline $\begin{array}{l}\text { Number of } \\
\text { rooms }\end{array}$ & Points & 0,1 & + & 6 & 7 & 7 & 5 & 7 & 8 & 8 & 8 & 7 & 9 & 9 & 8 \\
\hline $\begin{array}{l}\text { Construction } \\
\text { year }\end{array}$ & Points & 0,02 & + & 10 & 10 & 9 & 6 & 10 & 10 & 10 & 7 & 10 & 10 & 10 & 8 \\
\hline $\begin{array}{l}\text { Aplinkos } \\
\text { estetika }\end{array}$ & Points & 0,09 & + & 10 & 10 & 10 & 9 & 10 & 10 & 10 & 10 & 10 & 10 & 10 & 10 \\
\hline $\begin{array}{l}\text { Street } \\
\text { environment }\end{array}$ & Points & 0,06 & + & 10 & 10 & 10 & 8 & 10 & 10 & 10 & 9 & 9 & 10 & 10 & 8 \\
\hline $\begin{array}{l}\text { Public } \\
\text { transport }\end{array}$ & Points & 0,12 & + & 9 & 10 & 10 & 10 & 9 & 10 & 10 & 10 & 9 & 10 & 10 & 10 \\
\hline Price & Points & 0,2 & - & 4 & 7 & 8 & 6 & 5 & 8 & 9 & 7 & 6 & 9 & 9 & 8 \\
\hline Green areas & Points & 0,14 & + & 8 & 10 & 10 & 10 & 9 & 10 & 10 & 9 & 8 & 10 & 10 & 9 \\
\hline $\begin{array}{l}\text { Commercial } \\
\text { services }\end{array}$ & Points & 0,09 & + & 8 & 9 & 9 & 8 & 9 & 10 & 10 & 9 & 8 & 10 & 10 & 9 \\
\hline $\begin{array}{l}\text { Cultural and } \\
\text { sporting } \\
\text { services }\end{array}$ & Points & 0,08 & + & 10 & 10 & 9 & 6 & 10 & 10 & 10 & 7 & 10 & 10 & 10 & 8 \\
\hline Heart rate & Points & 0,05 & + & 71,65 & 74,49 & 84,31 & 82,80 & 79,46 & 76,39 & 82,94 & 91,12 & 77,85 & 78,16 & 76,01 & 70,18 \\
\hline Happy & Points & 0,2 & + & 0,139 & 0,108 & 0,085 & 0,070 & 0,130 & 0,115 & 0,083 & 0,075 & 0,134 & 0,116 & 0,101 & 0,104 \\
\hline Sad & Points & 0,05 & + & 0,191 & 0,141 & 0,121 & 0,109 & 0,192 & 0,160 & 0,157 & 0,112 & 0,190 & 0,157 & 0,146 & 0,149 \\
\hline Angry & Points & 0,05 & + & 0,115 & 0,099 & 0,100 & 0,087 & 0,094 & 0,102 & 0,102 & 0,103 & 0,104 & 0,105 & 0,108 & 0,110 \\
\hline Valence & Points & 0,15 & + & $-0,224$ & $-0,097$ & $-0,107$ & \begin{tabular}{|l|}
$-0,099$ \\
\end{tabular} & $-0,107$ & \begin{tabular}{|l|}
$-0,098$ \\
\end{tabular} & $-0,139$ & $-0,118$ & $-0,104$ & $-0,096$ & $-0,114$ & $-0,101$ \\
\hline \multicolumn{4}{|c|}{$\begin{array}{l}\text { Utility degree of housing unit video } \\
\text { alternatives under comparison (\%) }\end{array}$} & 100,0 & 64,45 & 59,30 & 71,84 & 82,79 & 59,30 & 55,64 & 64,45 & 71,84 & 55,64 & 55,64 & 59,30 \\
\hline \multicolumn{4}{|c|}{$\begin{array}{l}\text { Priority of housing unit video } \\
\text { alternatives under comparison }\end{array}$} & 1 & 6 & 7 & 4 & 2 & 9 & 12 & 5 & 3 & 10 & 11 & 8 \\
\hline
\end{tabular}

* The symbol "+/-" specifies that a bigger (smaller) criterion value corresponds to a bigger (smaller) importance for a user (stakeholder)

The COPRAS method [52] and the data from Table 3 has been used to define the possible result of the video ads being examined on passers-by. A multicriteria analysis of alternatives, performed with the application of the VINERS method, indicated that the group ranging in the ages of 20-30 years was the most receptive to the advertisement and showed the greatest interest in the projects under development (see Table 3).

\section{Conclusions}

The researches described in the introduction indicate that a specific demographic segment of buyers would be best off looking for a dwelling in the same area where they usually feel well. In other words, people are best off living where they feel best.

The best $[20,32,36]$ and worst $[9,20]$ places to live have been analysed in the world for many years and multiple criteria analysis has been used for that purpose [22]. Other studies $[3,31,42,53]$ also have analysed the environment that contributes to higher or lower positive emotions and happiness.

$\mathrm{Lu}$ [31] made a review of 178 published articles and was the first to look beyond the physiological and environmental effects of air pollution and take a systematic look at its psychological (affective, behavioural, cognitive), social and economic effects. Air pollution contributes to 
decreased happiness and life satisfaction and increased anxiety, annoyance, self-harm, mental disorders, and suicide [31]. Benita et al. [3] determined a positive correlation between immediate environmental factors, public spaces and happiness. Benita et al. [3] unique contribution is the estimation, by using nearly real-time data, of the impact places, environment, and personal characteristics make on momentary happiness. To make people more happy, which is important to their well-being, planners are recommended to focus on designs that support opportunities for social interaction, make people feel safer in the environment, and increase access to open green spaces [42]. Zhang et al. [54] estimate the monetary value of cutting $\mathrm{PM}_{2.5}$, one of the main sources of air pollution in China. Zhang et al. [53] matched the hedonic happiness values from a representative country-level survey with daily air quality parameters by the dates and counties of interviews in China and determined how local concentration of particulate matter is related to individual happiness.

Over the course of the research, over 250 million items of data have been gathered on 17 AEPS parameters (see Figure 1) of these depersonalized passersby. Our investigation has looked at the dynamic links between positive emotions and happiness of people and their built environment. Our research shows that the innovative VINERS method is an essential new addition to multiple criteria neuromarketing analysis of integrated sustainable development, positive emotions, happiness and built environment. The research determines rational segments of homebuyers by their demographic profiles (age, gender, education, marital status, families with children, main source of income), consumer psychographics and behaviour (happy, sad and angry along with valence and heart rate). This article also presents a case study to demonstrate the VINERS method put to practice.

The research confirmed our hypothesis that in housing neuromarketing an integrated approach is required to consider the most rational customer segments, the desired features of an apartment, individual differences, environmental influences on property, emotional and physiological states, valence and arousal and affective attitudes. By applying the Neuro Decision Tables, the above data can be used in neuromarketing to discover the most rational customer segments and to perform multiple criteria analysis of video ads.

Certain limitations of the research were also noticed during the time of the case study. For example, this study only encompassed real estate examples, which the ViNeRS Method then verified. The future expectation is to apply the neuro decision matrix and the ViNeRS Method more broadly, performing neuro-marketing for business, services, industry, agricultural organizations, relationships and social units. Furthermore, it is foreseen to supplement the neuro decision matrix on real estate with new criteria for more accurate descriptions of the objects under deliberation.

When someone advertises a home for sale, they usually consider the individual differences of potential homebuyers, their desires for the flat or house (indoor environmental quality and human health; energy, water, and materials efficiency; recycled, reusable and low-impact building materials; waste reduction; low-carbon technologies; renewable energy sources), and the environmental influences (air, noise and water pollution, green architecture, green built environment, etc.) on the property. The affective reactions, physiological and emotional status, arousal and valence of potential buyers are only considered in real estate advertising in exceptional cases. But so far all these factors have never been considered as an integrated whole. This study aimed to take an integrated look at the physiological and emotional status of potential homebuyers, their affective reactions, individual differences, arousal and valence, as well as environmental influences on properties and the preferred features of homes. The above data in this study was used in multiple criteria analysis of video ads and neuromarketing; different customer segments were analyzed by means of Neuro decision matrices. This research adds new pieces to "the big picture" of neuromarketing in green housing sales. This study, however, does not fully answer 
some questions and many new questions have surfaced. In future studies, for instance, we intend to include a more extensive application of biometric and affective computing technologies in the ViNeRS method.

\section{Acknowledgment}

This project has received funding from European Regional Development Fund (project No 01.2.2-LMT-K-718-01-0073) under grant agreement with the Research Council of Lithuania (LMTLT).

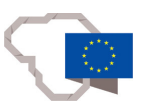

\section{Bibliography}

[1] Azimi, P.; Zhao, H.; Fazli, T.; Zhao, D.; Faramarzi, A.; Leung, L.; Stephens, B. (2018). Pilot study of the vertical variations in outdoor pollutant concentrations and environmental conditions along the height of a tall building, Building and Environment, 138, 124-134, 2018.

[2] Belch, G.E.; Belch, M.A. (2012). Advertising and Promotion: An integrated marketing communications perspective. McGraw-Hill Irwin, New York, 2012.

[3] Benita, F.; Bansal, G.; Tunçer, B. (2019). Public spaces and happiness: Evidence from a large-scale field experiment, Health \& Place, 56, 9-18, 2019.

[4] Bigné, J. E.; Andreu, L. (2004). Emotions in segmentation: An empirical study, Annals of Tourism Research, 31(3), 682-696, 2004.

[5] Bondi, L.; Davidson, J.; Smith, M. (2016). Introduction: Geography's 'emotional turn', In Emotional geographies, Routledge, 15-30, 2016.

[6] Chapman, D. W.; Lombard, J. R. (2006). Determinants of neighborhood satisfaction in fee-based gated and non-gated communities, Urban Affairs Review, 41(6), 769-799, 2006.

[7] Cloutier, S.; Berejnoi, E.; Russell, S.; Morrison, B.A.; Ross, A. (2018). Toward a holistic sustainable and happy neighborhood development assessment tool: A critical review of relevant literature, Ecological Indicators, 89, 139-149, 2018.

[8] Cloutier, S.; Pfeiffer, D. (2015). Sustainability through happiness: A framework for sustainable development, Sustainable Development, 23(5), 317-327, 2015.

[9] Cook, R.; Wainer, H. (2017). Joseph Fletcher, thematic maps, slavery, and the worst places to live in the UK and the US, Visible Numbers, Routledge, 83-105, 2017.

[10] D'Acci, L. (2019). Quality of urban area, distance from city centre, and green housing value. Case study on real estate values in Turin, Cities, 91, 71-92, 2019.

[11] Dahl, S.; Gordon-Wilson, S.M. (2013). Advertising assertiveness and effectiveness: the role of product involvement, Proceedings of the Academy of Marketing, Marketing Relevance, Glamorgan, Wales, 1-6, 2013. 
[12] Del Chiappa, G.; Andreu, L.; G. Gallarza, M. (2014). Emotions and visitors' satisfaction at a museum, International Journal of Culture, Tourism and Hospitality Research, 8(4), 420-431, 2014.

[13] Dzitac, D. (2019). Extending Curiosity: The Power of Exploring Options, Oral presentation at NYU Global Engagement Symposium, New York University, New York City, April 5th, 2019 .

[14] Florida, R.L. (2009). Reports what qualities of cities and towns actually make people happy, 2009.

[15] Florida, R. L. (2009). Who's your city?: How the creative economy is making where to live the most important decision of your life, Vintage Canada, 2009.

[16] Florida, R.; Mellander, C.; Rentfrow, P. J. (2013). The happiness of cities, Regional studies, 47(4), 613-627, 2013.

[17] Galvín, P.; López Mendoza, D.; Connolly, D.P.; Degrande, G.; Lombaert, G.; Romero A. (2018). Scoping assessment of free-field vibrations due to railway traffic, Soil Dynamics and Earthquake Engineering, 114, 598-614, 2018.

[18] Gesler, W. (2003). Healing Places Lanham MD, Rowman and Littlefield, 2003.

[19] Gibler, K.M.; Taltavull de La Paz, P.; Zahirovic-Herbert, V. J. (2018). Residents' evaluation of advantages and disadvantages of golf community living in Alicante, Spain. Green housing and the Built Environment, 33(4), 731-748, 2018.

[20] Granger, M.; Price, G. N. (2015). Are States with Larger than Average Black Populations Really the Worst Places to live in the USA? A Spatial Equilibrium Approach to Ranking Quality of Life, Journal of Public Management \& Social Policy, 20(2), 3, 2015.

[21] Grum, B.; Salaj, A.T. (2010). Expectations of potential acquisitions of residential real estate rights in the republic of Slovenia, according to gender, age, education and employment, Geodetski vestnik, 54(3), 501-516, 2010.

[22] Hoepfner, G. K.; Mata, F. (1993). A multi-criteria decision analysis methodology for selection of a preferred residence based on physical attributes, Computers \& industrial engineering, 25(1-4), 365-368, 1993.

[23] Hosany, S.; Prayag, G. (2013). Patterns of tourists' emotional responses, satisfaction, and intention to recommend, Journal of Business Research, 66(6), 730-737, 2013.

[24] Hubbard, P. (2016). The geographies of 'going out': Emotion and embodiment in the evening economy, In Emotional geographies, Routledge, 131-148, 2016.

[25] James, R. N. (2008). Residential satisfaction of elderly tenants in apartment green housing, Social Indicators Research, 89, 421-437, 2008.

[26] Kaklauskas, A. (1999). Multiple criteria decision support of building life cycle, research report presented for habilitation (DrSc), Technological Sciences, Civil Engineering (02T). Technika: Vilnius Gediminas Technical University, Vilnius, 1999.

[27] Lawless, N. M.; Lucas, R. E. (2011). Predictors of regional well-being: A county level analysis, Social Indicators Research, 101(3), 341-357, 2011. 
[28] Li, M.; Bao, Z.; Sellis, T.; Yan, S.; Zhang, R. (2018). HomeSeeker: A visual analytics system of real estate data, Journal of Visual Languages \& Computing, 45, 1-16, 2018.

[29] Lithuanian Department of Statistics. (2018). Segmentation of consumers by age and gender at select districts. Accessed date: 29 September 2018

[30] Leyden, K.M.; Goldberg, A.; Michelbach, P. (2011). Understanding the pursuit of happiness in ten major cities, Urban Aff. Rev. 47 (6), 861-888, 2011.

[31] Lu, J. G. (2019). Air Pollution: A Systematic Review of Its Psychological, Economic, and Social Effects, Current Opinion in Psychology, In Press, Journal Pre-proof.

[32] Méndez, M. L.; Gayo, M. (2019). Inheritors, Achievers, and Incomers: Wrapping Up a Multidimensional Approach to Social Reproduction, In Upper Middle Class Social Reproduction, Palgrave Macmillan, Cham, 135-145, 2019.

[33] Milligan, C.; Bingley, A.; Gatrell, A. (2016). "Healing and feeling": The place of emotions in later life, In Emotional geographies, Routledge, 63-76, 2016.

[34] O'Brien, C. (2005). Sustainable happiness: harmonizing our internal and external landscapes, 2nd International Conference on Gross National Happiness, Antigonish, Nova Scotia, 2005.

[35] O'Brien, C. (2008). Sustainable happiness: how happiness studies can contribute to a more sustainable future, Can. sychol./Psychologie canadienne, 49(4), 289, 2008.

[36] O'Hara, M. (2016). Make it personal: International Futures Forum's Approach to community transformation, In Transforming Communication in Leadership and Teamwork, Springer, Cham, 99-106, 2016.

[37] Papamanolis, N. (2014). An Overview of the Architectural Methods Used to Manage the Variable Environmental Influences on Buildings in the Mediterranean Region, Journal of Architectural Engineering Technology, 3(3), 2014.

[38] Papamanolis, N. (2006). An Approach to the Effects of Environmental Change on Building Design and Construction, 23rd Conference on Passive and Low Energy Architecture, Geneva, Switzerland, 2006.

[39] Paralkar, S.; Cloutier, S.; Nautiyal, S.; Mitra, R. (2017). The sustainable neighborhoods for happiness (SNfH) decision tool: Assessing neighborhood level sustainability and happiness, Ecological Indicators, 74, 10-18, 2017.

[40] Parkes, A.; Kearns, A.; Atkinson, R. (2002). What makes people dissatisfied with their neighbourhoods? Urban Studies, 39, 2413-2438, 2002.

[41] Perez, F. R.; Fernandez-Mayoralas, G.; Rivera, F. E. P.; Abuin, J. M. R. (2001). Ageing in place: Predictors of the residential satisfaction of elderly, Social Indicators Research, 54, 173-208, 2001.

[42] Pfeiffer, D.; Cloutier, S. (2016). Planning for happy neighborhoods, Journal of the American planning association, 82(3), 267-279, 2016.

[43] Phillips, D. R.; Siu, O. L.; Yeh, A. G. O.; Cheng, K. H. C. (2005). The impacts of dwelling conditions on older persons' psychological well-being in Hong Kong: The mediating role of residential satisfaction, Social Science and Medicine, 60, 2785-2797, 2005. 
[44] Pitarma, R.; Lourenço, M.; Ramos, J. (2016). Improving occupational health by modelling indoor pollutant distribution, Facilities, 34(5/6), 289-301, 2016.

[45] Rentfrow, P. J.; Mellander, C.; Florida, R. (2009). Happy states of America: A state-level analysis of psychological, economic, and social well-being, Journal of Research in Personality, 43(6), 1073-1082, 2009.

[46] Respizzi, S.; Covelli, E. (2015). The emotional coaching model: quantitative and qualitative research into relationships, communication and decisions in physical and sports rehabilitation, Joints, 3(4), 191-200, 2015.

[47] Tam, N.D. (2015). Quantitative Assessment of Sad Emotion, Psychology and Behavioral Sciences, 4(2), 36-43, 2015.

[48] Tan, T-H. (2012). Green housing satisfaction in medium- and high-cost green housing: The case of Greater Kuala Lumpur, Malaysia, Habitat International, 36(1), 108-116, 2012.

[49] Urry, J. (2016). The place of emotions within place, In Emotional geographies,Routledge, 91-98, 2016.

[50] Xu, X.; Zhong, Z.; Deng, S.; Zhang, X. (2017). A review on temperature and humidity control methods focusing on air-conditioning equipment and control algorithms applied in small-to-medium-sized buildings, Energy and Buildings, 162, 163-176, 2017.

[51] Yang, J.; Zhou, Q.; Liu, X.; Liu, M.; Qu, S.; Bi, J. (2018). Biased perception misguided by affect: How does emotional experience lead to incorrect judgments about environmental quality? Global Environmental Change, 53, 104-113, 2018.

[52] Zavadskas, E. K.; Kaklauskas, A.; Sarka, V. (1994). The new method of multicriteria complex proportional assessment of projects, Technological and economic development of economy, 3, 131-139, 1994.

[53] Zhang, X.; Zhang, X.; Chen, X. (2017). Valuing air quality using happiness data: the case of China, Ecological economics, 137, 29-36, 2017.

[54] Zhang, X.; Zhang, X.; Chen X. (2017). Happiness in the air: How does a dirty sky affect mental health and subjective well-being? Environmental Economics and Management, 85, 81-94, 2017.

[55] Zidansek, A. (2007). Sustainable Development and Happiness in Nations, Energy, 32, 91$897,2007$. 